\title{
Basis and Practices of Restorative Justice: The Case of the Ethiopian Criminal Justice System
}

\author{
Negesse asnake Ayalew ${ }^{1}$ \\ ${ }^{1}$ Ethiopian Police University College, Ethiopia
}

\begin{abstract}
Keywords: Access to justice, Restorative Justice, Retributive System, Victim Participation

Purpose of the study: The Ethiopian criminal justice system views crime as an offense against the state. and is not allowed the participation of the victim and the community and also win-loss outcome. Scholars have established the concept of restorative justice which views crime as a violation of the relationship among the victims, offenders and community. Therefore, the purpose of this paper is to assess the legal and institutional basis and practice of restorative justice in Ethiopia.
\end{abstract}

\begin{abstract}
Methodology: This study employs a qualitative research approach and descriptive research design. The population of this study includes the victims, offenders, criminal justice system components and traditional dispute resolver. Data was collected through document review and the interview of five individuals selected through the purposive sampling technique. The collected data was then analyzed thematically.
\end{abstract}

\begin{abstract}
Main Findings: The results show that different governmental institutions such as the house of federation, peace minster, police, court, general attorney, and reconciliation commission have a legal recognition to apply restorative justice values and principles. Meanwhile, traditional conflict resolution mechanisms and alternative dispute resolution mechanisms have defector recognition to resolve criminal cases.
\end{abstract}

Research limitations/implications: The models of restorative justice in Ethiopia entail compromise, withdrawal of charge, probation, pardon, amnesty, plea bargaining, shuttle diplomacy, suspect rehabilitation and reconciliation based on different laws. Therefore, the house of people representative should enact a comprehensive law on restorative justice. The police and general attorney should create awareness about restorative justice.

Novelty/Originality of this study: Restorative justice has many benefits, but the concept itself has not been studied in detail. This study is the first of its kind to examine restorative justice in detail in the context of Ethiopia.

\section{INTRODUCTION}

Conflict is a part of human existence caused by limited resources to fulfill unlimited human needs. Conflict is neither destructive nor constructive, but its mechanism of management is determined. When resolved by force, it will escalate into violence (crime) and even war. When resolved by formal criminal justice system and informal conflict resolution mechanisms, it promotes development, peace and democracy (Galtung, 2004).

The criminal justice system (CJS) is the process of crime investigation carried out by the police, prosecution by the public prosecutor, adjudication by the court and enforcement of punishment by correctional institutions. However, it excludes the participation of stockholders and the process is adversarial with a win-loss outcome. In order to address these disadvantages of the CJS, criminologists introduced the concept of restorative justice which allows the participation of stockholders and a win-win outcome (Zehr, Komiyama, \& Stein, 1997).

To the author's best knowledge, existing studies on restorative justice in Ethiopia are too general and vague. Therefore, the writer is motivated to assess the practice and models of restorative justice and the mechanisms of collaboration with the criminal justice system in order to ensure the right to justice. This paper is organized into four sections. The first section presents a general overview of restorative justice. The second section explains the legal and institutional framework of restorative justice in Ethiopian (Zehr et al., 1997). The third section discusses the practice of restorative justice in Ethiopia. The final section presents the conclusion and suggestions for future studies.

\section{METHODOLOGY}


This study employed a qualitative research approach and descriptive research design. The population of this study consisted of the victims, offenders, criminal justice system components and traditional dispute resolver. Data was collected through document review and interview of five individuals selected through the purposive sampling technique. The collected data was then analysed thematically. The data is from primary and secondary sources. The scope of this study is the models of restorative justice in Ethiopia (Zehr et al., 1997).

\section{GENERAL OVERVIEW OF RESTORATIVE JUSTICE}

This section deals with the rationale for restorative justice and the differences between ADR, customary dispute resolution, informal conflict resolution mechanism and restorative justice.

\subsection{Rational and Definition of Restorative justice}

Conflicts are a part of social life. Before the emergence of modern government, the society resolved its conflict through informal conflict resolution mechanisms, which can be classified into either traditional dispute resolution or popular justice forums (alternative dispute resolution, which will be discussed below) (McCold, 1998).

The phrase 'traditional (indigenous) or customary dispute resolution' refers to resolution of conflict by local law and traditional judges, which is effective in most distinct communities due to the cosmo-vision behind this communal character known as 'indirect reciprocity', which is characterized by two elements (McCold, 1998). Firstly, members of a community are not primarily seen as individuals with individual rights and duties, and they are not perceived as equal citizens. Instead, they are deemed to belong to one category or status out of a wide range of different categories of people such as being a member of the same age-set, or being a part of an important clan/sub-clan, or being a man or a woman or a child or an adult, etc. Secondly, for every category of members, there exists the obligation to sometimes restrain from pursuing only individual interests. Everyone in his own place in the community is obliged during times of trouble to take care of others and their welfare in general, trusting that other members of the community will help him/her in the future in case he/she gets into trouble. Additionally, people are expected to know about the kind of behaviour that is expected from them such as how a woman or a child is supposed to behave. There is not much room for personal and private interests and hobbies especially those that would be disruptive to the community (Fekadu, 2009)..

Therefore, the local laws of these distinct communities are more of a collection of broad, unwritten and "vague" principles that everyone has to obey. When someone deviates from those principles, he is considered to be disrespectful to the community and nature. How to deal with this un-orderly behaviour? Here, the central question about the suspect is not exclusively if whether he/she can be proven to have done the offence. In determining someone's guilt, it is partly also a matter of determining if the suspect is a good or bad member of the community, and how he/she behaves morally. Therefore, doing justice is not what in the CJS would be called a purely "legal" matter, but is more of an evaluation of the totality of someone's relations, whether or not that person is a good and regular worker or whether he conforms to the morals and ways of life of the community.

The phrase popular justice forum or Alternative Dispute Resolution (ADR) refers to a non-state judicial determination including the process of negotiation between disputing parties up to the intervention of a neutral third party (mediator or conciliator) to resolve a certain dispute. Negotiation is the process of bilateral discussion between conflicting parties without the intervention of a third party in order to solve their dispute (Fekadu, 2009). Mediation is a voluntary, party-centered and structured negotiation process where a neutral third party facilitates the negotiation process. The conciliator plays the role of an advisor to the disputing parties, which may propose certain terms of compromise. The advantages of negotiation, mediation and conciliation as compared to arbitration and court litigation are that they are cheaper, party controlled upon initiation up to outcome, confidential, private, speedy, and timely with a win-win result. Its demerit is that an imbalance of power occurs between the disputing parties during the dispute resolution proceeding, absence of precedent, lack of consent of a party and problems related to the enforcement of compromise (Fekadu, 2009). Black's law dictionary (1997) defines 'Arbitration' as a method of legal dispute resolution involving one or more neutral third parties who are usually agreed to by the disputing parties and whose decision is binding. Arbitration is not an Alternative Dispute Resolution because it has an adversarial procedure and win-loss award like a court judgment and is unable to restore the former relationship between the conflicting parties. ADR is a contract while Arbitration is a form of Adjudication, which means that arbitration recognizes the principles of a fair hearing such as the right to present one's own version of the case, the right to produce evidence, the right to challenge an opposing evidence and argument, and so on. Additionally, the outcome of arbitration is a binding award that is almost similar to a court judgment; the role of the arbitrator is also similar to a court judge. In the case of negotiation and mediation, the principle of fair hearing like adversarial litigation is unthinkable; it is rather the process of working together to satisfy the involved parties' mutual interest (Fekadu, 2009).

The Alternative Dispute Resolution mechanism is effective in a functional society, which refers to the existence of direct reciprocity usually in urban and per-urban areas where no traditional justice system had previously existed and in rural areas where the traditional system has broken down. It is based on the conflicting parties' consent to initiate and place as well 
as the law \& language of the proceeding with a win-win outcome. ADR is created through the amendment of a traditional dispute resolution mechanism and is run by non-governmental organizations.

After the emergence of the modern state, the criminal justice components had attempted to monopolize resolution of criminal cases and also consider traditional conflict resolution mechanism as an obstacle against development and national unity. The criminal justice system is only expected to strike a balance between the protections of the public against criminal harm with suspects against unfair treatment along the process. However, it was criticised as being expensive, inaccessible, conflict-inducing, and disempowering for those involved, with a prevalence of a mistrust of the law, fear, intimidation, unfamiliarity of formal procedures and court atmosphere, low legal literacy, and unequal power relations. On the other hand, the informal conflict resolution mechanism is seen as a more accessible, flexible and efficient form of justice which allows for the active participation of all parties and assists in the preservation of relationships. Therefore, the rationale for the emergence of restorative justice $(\mathrm{RJ})$ is to rectify the limitations associated with the criminal justice system.

There is no universally accepted definition for the term restorative justice $(\mathrm{RJ})$ due to the growing nature of the field. It originated from the criminal justice practices of indigenous peoples and the alternative dispute resolution system around the world. The state should support and control restorative justice in order to limit its demerits. For instance, the indigenous dispute resolution mechanism violates the human rights of the minority, children and women. So the state controls such disadvantages. Therefore, it is defined as simple as opposed to formal criminal justice system behaviors as follows:

Table. 1

The difference between Criminal Justice and Restorative Justice

\begin{tabular}{|c|c|c|c|}
\hline$\ddot{\sharp}$ & \multicolumn{2}{|c|}{ Criminal Justice } & Restorative justice \\
\hline$\sum_{\overparen{\Xi}} n$ & & Victims are not the primary focus of the process. & $\begin{array}{l}\checkmark \quad \text { Victims and community are directly involved and play a key role } \\
\text { in response to misbehaviours/offenses. }\end{array}$ \\
\hline \multirow{2}{*}{$\frac{n}{2}$} & & Offenders are defined by the misbehaviour/offense. & $\begin{array}{l}\checkmark \quad \text { Offenders are defined by their capacity to take responsibility for } \\
\text { their actions and changed behaviour. }\end{array}$ \\
\hline & & Victim is defined by material and psychological loss. & $\begin{array}{l}\checkmark \quad \text { Victims are defined by losses and capacity to participate in the } \\
\text { process for recovering losses and healing. }\end{array}$ \\
\hline 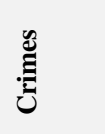 & & $\begin{array}{l}\text { Crimes are the result of individual choice with individual } \\
\text { responsibility. } \\
\text { Crime is a violation of the law, and the state is the victim. }\end{array}$ & $\begin{array}{l}\checkmark \quad \text { Crimes have both individual and social dimensions and are the } \\
\text { result of individual choice and the conditions that lead to the } \\
\text { behaviour. } \\
\checkmark \quad \text { Crime is a violation or harm to people and relationships. }\end{array}$ \\
\hline$\frac{\Xi}{0}$ & & $\begin{array}{l}\text { Defined narrowly, } \\
\text { Abstract (a legal fiction), } \\
\text { Only legal variables are relevant, } \\
\text { State as the victim. }\end{array}$ & $\begin{array}{ll}\checkmark & \text { Defined relationally, } \\
\checkmark & \text { A violation of people, } \\
\checkmark & \text { Overall context is relevant, } \\
\checkmark & \text { People as victims. }\end{array}$ \\
\hline :气 & $>$ & State is active and but offender passive. & $\begin{array}{l}\checkmark \quad \text { Victim and offender primary, along with the community and } \\
\text { state. }\end{array}$ \\
\hline \multirow{4}{*}{ 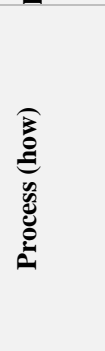 } & & Adversarial, authoritarian, technical, impersonal. & $\begin{array}{l}\checkmark \quad \text { Participatory, maximizing information, dialogue and mutual } \\
\text { agreement. }\end{array}$ \\
\hline & & Focus - guilt/blame. & $\checkmark \quad$ Focus -needs and obligations. \\
\hline & & $\begin{array}{l}\text { Neutralizing strategies, } \\
\text { Encouraged }\end{array}$ & $\begin{array}{ll}\checkmark & \text { Empathy and responsibility } \\
\checkmark & \text { Encouraged }\end{array}$ \\
\hline & & $\begin{array}{l}\text { The process of justice is a conflict between adversaries in } \\
\text { which the offender is pitted against state rules; intentions } \\
\text { outweigh outcomes and one side wins while the other loses. }\end{array}$ & $\begin{array}{l}\checkmark \quad \text { The process involves victims, offenders and the community in an } \\
\text { effort to identify obligations and solutions, maximizing the } \\
\text { exchange of information (dialogue, mutual agreement) between } \\
\text { them. }\end{array}$ \\
\hline \multirow{3}{*}{$\stackrel{\stackrel{\Xi}{\Xi}}{\stackrel{\Xi}{\Xi}}$} & & $\begin{array}{l}\text { Pain and suffering. } \\
\text { Harm by offender balanced by harm to offender. }\end{array}$ & $\begin{array}{l}\checkmark \quad \text { Making things right by identifying needs and obligations, } \\
\text { healing, problem-solving. } \\
\checkmark \quad \text { Harm by offender balanced by making right. }\end{array}$ \\
\hline & & Oriented to the past. & $\checkmark \quad$ Oriented to the future. \\
\hline & & $\begin{array}{l}\text { The aim of justice is to establish blame (guilt) and administer } \\
\text { pain (punishment). }\end{array}$ & $\begin{array}{l}\checkmark \quad \text { The aim of justice is to identify obligations, to meet needs and to } \\
\text { promote healing. }\end{array}$ \\
\hline
\end{tabular}

Source: (Zehr, 1997).

Therefore, for the purpose of this paper, Restorative Justice refers to the defacto or dejuries recognition of traditional dispute resolution and alternative dispute resolution by the state to resolve criminal matters in collaboration with the state criminal justice system. This entails the sharing of sovereign resolution of criminal matter to non-state institutions. RJ provides a much greater degree of participation of stockholders, offers ample opportunity for apologies, forgiveness, reduced fear and anger, and strength in future relationships. It can proceed in a court room proceeding and employ pre-trial diversion, dismissing charge after institution and also in more serious cases, prison sentence may proceed in other restitution. It can also 
proceed in the community such as the concerned community meeting with all parties to assess the experience and impact of the crime.

\subsection{Principles of Restorative Justice}

The values of restorative justice are respect for the dignity of the individual in the context of the administration of criminal justice and the participation of victims and offenders in the process of conflict resolution in order to compensate the harm caused by the offender. The three basic assumptions of restorative justice are that the crime is viewed as a violation of people and relationships, violations give rise to obligations and finally, the resulting obligation is to put wrongs to right (Zehr, 1997). Based on these assumptions, the principles of restorative justice are: firstly, every stakeholder has the right to participate through the conflict resolution process. Secondly, the procedure is voluntary, cooperative and flexible. Thirdly, the community's disapproval of wrong doing is accompanied by acts to reintegrate the offender back into the community of law abiding citizens through words or gestures of forgiveness or ceremonies to decertify the offender as deviant. Finally, repairing the harms by imposing obligations on the offender and the communities for restitution, or performance of community services, making apology by the offender and showing sincere remorse in a way that helshe acknowledges his wrongful acts (Endalew, $\underline{2013})$.

\subsection{Models of Restorative Justice}

$\mathrm{RJ}$ is a new concept but its influence has spread around the world at an amazing speed through innovation and integration of restorative justice values and principles into the global justice systems. This program or model does not exhibit a uniformed structure and form because the essence of restorative justice is not the adoption of one form or process; rather, it is the adoption of any form or process which fills the limitations of the criminal justice system. Hence, depending on the choice of the parties, types of conflict and resources, there are different restorative justice programs functioning in different countries (Endalew, 2013). Among these, the most common are:

\subsubsection{Victim-Offender Mediation}

The mediation is a neutral third party that facilitates the process of negotiation between the victim and the offender in order to resolve their conflict. It is similar with mediation processes in civil matters, which was first trialled in Ontario, Canada then expanded throughout the United States, the United Kingdom and Europe in the early 1970s.The features of victim-offender mediation include permitting victims to meet their offenders on a voluntary basis, encouraging the offender to learn about the crime's impact \& to take responsibility for the resulting harm, and providing the victim and the offender the opportunity to develop a plan that addresses the harm. Its outcome is win-win, giving satisfaction for the victims and offenders, lowering fear among victims, providing a greater likelihood that the offender will complete a restitution obligation, and assuring that fewer offenders will commit new offences than the normal court process (Endalew, 2013).

\subsubsection{Family or Community Group Conferencing}

This is an extension of the victim-offender mediation through the collaboration between the victim, offender, and family, friends and key supporters to resolve the conflict together. Conferencing allows the victim an opportunity to be directly involved in responding to the crime, increasing the offender's awareness of the impact of his or her behaviour and providing an opportunity to take responsibility for it, engaging the offenders' support system for making amends and shaping the offender's future behaviour, and allowing the offender and the victim to connect to key community support. It originated from Maori traditional practices in New Zealand, where it is operated out of the social services department, and further modified in Australia for use by the police. It is now being used in North America, Europe, and southern Africa (Endalew, 2013).

\subsubsection{Peace-making or Sentencing Circles}

This is a process designed to develop consensus among community members, victims, victim supporters, offenders, offender supporters, judges, prosecutors, defence counsel, police and court workers on an appropriate sentencing plan that addresses the concerns of all the interested parties. It is a court annexed traditional conflict resolution mechanism, in which the court gets a sentence opinion from the community instead of the public prosecutor. The goals of circles include promoting the healing of all affected parties; giving the offender the opportunity to make amends; giving the victims, offenders, family members and communities a voice and shared responsibility in finding constructive resolutions; addressing underlying causes of criminal behaviour, and building a sense of community around shared community values. Circles were adapted from certain Native American traditional practices, and are being used throughout North America (Dekeyser et al., 2013).

\section{FOUNDATION OF RESTORATIVE JUSTICE IN ETHIOPIA}

The purpose of this section is to explain the basis of restorative justice in Ethiopia. Disputes and resolutions are normal. Ethiopia has more than 80 nations, nationalities and peoples, all of which have their own traditional dispute resolution mechanism such as the institutions of Gadaa among the Oromo and the Shimagelle by the Amhara, in order to resolve their conflict through traditional conflict resolution. Moreover, after the emergency of modern state, the resolution of conflict is only attempted by the criminal justice system. However, due to the weakness of the criminal justice system, Ethiopia has legal

Please cite this article as: Ayalew, N. a. (2020). Basis and Practices of Restorative Justice: The Case of the Ethiopian Criminal Justice System. International Journal of Social Sciences and Economic Review, 2(3), 01-11. Doi: https://doi.org/10.36923/ijsser.v2i3.53. 
and factually recognized principles and values of restorative justice, which are discussed in the following subsections (Hill, 2002)(Hill, 2002).

\subsection{FDRE constitution}

This is the supreme law of Ethiopia. The Federal Democratic Republic of Ethiopia (FDRE) Constitution article 37(1) states that everyone has the right to bring a justifiable matter to a court of law or any other competent body with judicial power to access justice. In addition to this, article 9(1) of the constitution allows customary practice or a decision of an organ of state or a public official, which does not contravene with the constitution. Similarly, Constitution articles 34(5) and 78(5) describe the adjudication of disputes relating to personal and family cases by religious or customary laws established by parliament with the consent of the parties to the dispute. Constitution articles 39 and 88(2) also explain that the government shall respect the identity of Nations, Nationalities and Peoples and uphold the duty to strengthen ties of equality, unity and fraternity among them. This means that everybody has the right to access justice from the criminal justice system or restorative justice system. The government has the duty to respect, fulfil and protect the right to access justice.

\subsection{House of Federation}

The House of Federation is the upper house of the parliament, which is the representative body of the nations, nationalities and peoples of Ethiopia. It is vested with the constitutional mandate to manage conflicts, find solutions to disputes that may arise between states or the Federal and State governments as enshrined in the FDRE Constitution under Articles 48 and 62(6). Specifically, proclamation No. 251/2001 i.e. articles 32 and 33 state that it shall request the parties to resolve their conflict by peaceful means and discussion where their misunderstanding is other than border disputes. This means that the first means of conflict resolution between states is negotiation. The House of Federation shall also attempt to abridge their differences; if the concerned parties could not resolve their misunderstandings through discussion, they shall strive to find a solution via any mechanism possible be it traditional or modern ways of conflict prevention and resolution. Therefore, the House of Federation has the responsibility to facilitate the resolution of conflict through the criminal justice system and restorative justice.

\subsection{Peace Minster}

This minister was established based on Proclamation No.1097/2018 Articles 9(1) and 13(g) (p) (q), which is responsible for identifying factors that cause conflicts among communities, submit a study proposing recommendations to keep communities away from conflicts and instability, and implement the same upon approval. It also facilitates the resolution of disputes arising between Regional States i.e. by devising and implementing sustainable solutions. This minister has different departments to discharge these responsibilities such as conflict prevention and peace building, reconciliation commission and the federal police.

\subsection{Ethiopian Reconciliation Commission}

This was established based on proclamation number $1102 / 2018$, which has the following responsibilities to reconcile based on truth and justice the disagreement that developed among the peoples of Ethiopia for years because of different societal and political conflicts; to identify and ascertain the nature, cause and dimension of the repeated gross violation of human rights so as to fully respect and implement basic human rights, providing the victims of gross human rights abuses in different times and historical events with a forum to be heard and the perpetrators to disclose and confess their actions as a way of reconciliation and to achieve lasting peace; to establish free and independent institutions that inquire and disclose the truth of the sources, causes and extent of conflicts and of which take appropriate measures and initiate recommendations that enable lasting peace, and to prevent the future occurrence of such conflicts. For instance, the commission chairperson in the 2020 press conference stated that identifying the root causes of various conflicts will be the focus of the Commission over the coming three years. It makes preparations to discharge the responsibilities that the people and the government of Ethiopia had entrusted onto it including setting up its administrative structure and preparing budget proposals as well as holding consultations with stakeholders.

\subsection{Peace committee or forum}

The peace minster has policies and strategies to establish conflict management institutions hierarchically at federal and regional government levels throughout the country. There are also attempts, at State and local government levels, to create inter-governmental committees designed to manage inter-ethnic conflicts and related issues in the common borders of the States or between different ethnic groups of a State. Some neighbouring States have established Peace Committees at various levels of administrative hierarchies which meet regularly to monitor the peace and security of their localities and resolve any issues of ethnic conflicts that may arise. For instance, the Afar National Regional State had established Peace Committees at neighbouring Kebeles, Woredas and Zones with National Regional States of Tigray, Amhara and Oromia and also at the interstate level (Gilligan, Hoddinott, \& Taffesse, 2009). The federal government and regional states conducted several forums and councils in order to resolve mutual problems including the Joint House Speakers Forum, the Forums of Dialogue between the House of Federation and each Regional State, the Five Eastern Adjoining Regional States Joint Forum, the Oromia and Somali 
Regional States Joint Cooperation Forum, the Afar and Tigray, and Afar and Amhara Cooperation Forums, as well as the Amhara and Benishangul Gumuz Joint Cooperation Forum (Gilligan et al., 2009).

\subsection{The FDRE Criminal Justice Policy}

Ethiopia has introduced a new criminal justice policy in September 2015. According to this policy, the general principles guiding the referral of criminal cases to the informal dispute resolution mechanisms take into account the type of crime, the character of the accused, and the circumstances of the commission of the crime, if it is believed that the interests of the public and the victims are better protected by the use of customary dispute resolution mechanisms than the regular court system; if the accused or the offender is a youth (juvenile), female, disabled, elderly, non-recidivist criminal, and helshe is accused of crimes punishable with simple imprisonment and a reconciliatory agreement is reached between the accused and the victim.

It also provides the following specific conditions, which must be fulfilled to refer the criminal case to informal dispute resolution mechanisms which require the accused person to wilfully admit all ingredients of the crime and sincerely express his repentance in writing after receiving sufficient legal advice to that effect; the accused person must ask for forgiveness from the victim, and must express his her readiness to restitute or compensate the damage caused; and the accused person should be informed in advanced that helshe has the right to refuse the referral of the case to customary dispute resolution mechanisms, all of which are the basic elements in a restorative justice ideal (Gilligan et al., 2009).

Based on the above general principles and specific conditions, the police, prosecutors, and judges are given discretionary power to refer the criminal case any time to informal dispute resolution mechanisms.

\subsection{Ethiopian Criminal Law (substantive \& procedural)}

In order to implement the Ethiopian criminal justice policy, the substantive and procedural criminal laws are enacted. First, the Ethiopian Criminal Procedure Code Article 223 states that the atbia dagnia has jurisdiction to mediate minor offenses such as insult, assault, petty damage to property or petty theft where the value of the property stolen does not exceed five Ethiopian Birr. Where it is unable to achieve a compromise, it may sit with two assessors adjudicate on such offenses and upon conviction impose a fine not exceeding 15 Ethiopian Birr and also it shall cause a record to be kept which, among others, shall show the opinion of the assessors. Secondly, Accusation is a rule to set justice in motion but complaint is an exception for crimes which are punishable upon complaint and require the prior consent of the victim because public interests are not at stake as the offence does not endanger the society at large and the institution of proceedings against the will of the injured party might often be more harmful to him than the commission of an offence. For instance, Articles of the Criminal Code of 212 with 380(2), 399, 556 (1), 559(3), 560, 580, 581, 583, 593, 603, 606, 613, 625, 643(2), 646(2), 652, 658, 664, 667, 679, $678,680,685,686(1), 700,704,705,717-719,725$, and 726 are phrased as “....is punishable upon complaint with ..." or “...proceeding shall be instituted only upon complaint by the injured party...". When these offences are committed, it is up to the injured or related person to set justice in motion. The police, prosecutor and court first try to mediate them based on the Criminal procedure code Article 151. If the reconciliation is affected, it will be recorded by the court to have the effect of a judgment. However, if the reconciliation has not been made, the court continues to hear the case as ordinary prosecution, and all the rules and procedures of ordinary trial are followed. So the public prosecutor can refuse to institute a criminal charge due to insufficiency of evidence to justify conviction for crimes that are punishable only upon formal complaint. Thirdly, the FDRE General Attorney also enacted a directive number 14/2015 for the mediation of criminal matters, which states that for crimes punishable upon complaint case committed by non-recidivist and non-concurrent crime, the police or the public prosecutor should try to mediate the conflicting parties.

\section{PRACTICE OF RESTORATIVE JUSTICE IN ETHIOPIA}

This refers to the application of traditional conflict resolution and Alternative dispute resolution mechanisms for criminal case resolution. The state also supports it through the recognition and enforcement of its compromise, technical and budget support and also controls human right violations and procedural unfairness. Therefore, restorative justice for the purpose of this paper refers to the use of negotiation, mediation, conciliation, arbitration, and customary dispute resolution mechanisms for criminal cases in Ethiopia, which are discussed as follows:

\subsection{Compromise}

The outcome of negotiation and mediation process is a compromise or contract, which is law for contracting parties. Conflict is a part of life, and the victim and offender may resolve it through negotiation and mediation especially crimes punishable upon complaint (minor crime). When it is approved by a competent authority, it has res judicata effect. It is similar with victim-offender mediation model of restorative justice. Therefore, for crimes punishable upon complaint in Ethiopia, the victim has the option to resolve the case through negotiation or may refer it to mediation or may institute private prosecution.

\subsection{Withdraws of charge}

Proclamation No.943/2016 article 6(3)(e) states that the General Attorney has the responsibility to institute criminal case charges by representing the federal government, withdraw charges when found necessary in the interest of the public, and

Please cite this article as: Ayalew, N. a. (2020). Basis and Practices of Restorative Justice: The Case of the Ethiopian Criminal Justice System. International Journal of Social Sciences and Economic Review, 2(3), 01-11. Doi: https://doi.org/10.36923/ijsser.v2i3.53. 
resume withdrawn charges based on the directive enacted with consultation of the Prime Minister (emphases added). For instance, the General Attorney conducted a press conference on February 25/2020, which states that the government had suspended the charges of 63 suspects of corruption and human rights violation in consultation with the prime minister in order to promote democracy and national unity in Ethiopia. Additionally, the General Attorney conducted a press conference on March 25/2020 which states that the government had suspended the charges of 39 suspects of low participation in identity violence.

\subsection{Probation}

This entails the release of a convicted offender under the supervision of a probation officer subject to revocation upon default of the conditions attached to his her release pursuant to Articles 190-199 of the FDRE criminal code. The first form of probation is that the court may postpone the imposition of sentence for a specific period of time pursuant to Article 191 of the Criminal Code, which states that:

When the criminal has no previous conviction and does not appear dangerous and where his crime is punishable with fine (Art. 90), compulsory labour (Arts. 103 and 104) or simple imprisonment for not more than three years (Art. 106), the Court, after having convicted the criminal, may suspend the sentence and place the criminal on probation, where it is of the opinion that such decision will lead to the reform of the criminal.

The second form of probation is when the courts impose the sentence and order the suspension of its enforcement based on Article 192 and 194, which state that:

When the Court considers that the criminal whether previously sentenced or not (Art 194), shall receive a warning, it shall enter a conviction and pass sentence but may order that the enforcement of the sentence be suspended for a specified period of probation. It shall not be allowed where the criminal has previously already undergone a sentence of rigorous imprisonment or a sentence of simple imprisonment for a term exceeding three years and where he is sentenced again to one of these penalties for the crime for which he is tried without prejudice to the provisions regarding recidivism.

Regarding probation, one informant was told as:

Mr. John and Madam Aster had concluded marriage and had borne two children. One day, conflict arose between them where Mr. John became angry and bit her teeth by stone thus breaking all her teeth. When she shouted, the police arrived and took him to the police station. After investigations, the public prosecutor charged him for serious bodily injury while Madam Aster asked the court to withdraw the charges on her husband because he is the only means of income for the family and her children are facing hunger. Therefore, the judge decided a sentence of 5 years imprisonment and released him on probation for the sake of his family.

\subsection{Parole}

This is granted by the pardon committee after receiving recommendations from the prison administration and having taken into consideration the behavioral reform of the criminal. The Criminal Code (Art. 202) states that:

The requirements that must be fulfilled to allow parole are that the prisoner has to serve two-thirds of a sentence of imprisonment or twenty years in case of life imprisonment, the prisoner or the management of the institution must submit a petition and recommendation respectively, the criminal should present a tangible proof of behavioral reform during the period of imprisonment, the prisoner must repair or agreed with the victim or his her families to repair the harm caused, and that the character of the prisoner warrants the assumption that helshe will be of good conduct when released.

From this article, one of the requirements for releasing the prisoner on parole is that he/she must repair or agree with the victim or histher families to repair the harm caused, which is one of the principles of restorative justice. For instance, the Ethiopian government had released over 18,000 prisoners after the outbreak of COVID-19 pandemic in 2020. The General Attorney indicated that the decision to release the prisoners is made to reduce the number of causalities in coronavirus outbreaks in the prisons. Women with children, those who demonstrated good behaviour, older people and those who are suffering from serious illnesses are also selected to benefit from it. Meanwhile, if the prisoners released are found to re-engage in crimes, the Office of Attorney General has the right to cancel its pardon and bring them back to prison.

\subsection{Amnesty}

This is given by the legislative organ of government to a group or class of persons, usually for a political offense (Black's law dictionary, 1992). The FDRE Criminal Code Article 230 states that an amnesty may be granted in respect of certain crimes or certain classes of criminals, either absolutely or subject to certain conditions or obligations, by the appropriate competent authority, when circumstances seem to indicate that such a measure is expedient. The implementation of amnesty proclamation was ratified by the House of Peoples Representatives on July 20, 2018, which benefits individuals and groups who were detained for breaking and committing crimes that violated the annulled terrorism law and uplifted state of emergency, which will not include prisoners who are imprisoned for killing, corruption, and rape. It also quits on-going court processes and removes any criminal list of suspected individuals. Specially, this move will benefit all citizens in the 
country and abroad for crimes committed until May 7/2018. The amnesty committee will certify the beneficiary individuals, as stated by the attorney general.

The Attorney General indicated that the proclamation will help individuals who are accused of committing various political crimes and participating in public violence that may have put the constitution in danger such as criminal code articles $238,241,247,249,252,256,257,288,486$ and terrorism proclamation article 622/2001. Those who participated in activities that may have put the constitution in danger and violated constitutional ethics of both the Federal and Regional government will also benefit from the proclamation. Individuals and groups that are suspected of committing crimes by using weapons will be exempted. This includes those who participated in forcing government officials, religion leaders, and individual for economic and political gains. In the amnesty proclamation, suspected individuals will have the right not to be registered on the criminal list. Moreover, their court case will be terminated, and they could be accused for the same crime again. For instance, in 2019 the Ethiopian government said that the amnesty was made to promote national reconciliation and to enhance democracy. Over 13,000 people have been pardoned under Ethiopia's amnesty law including lift designations of terrorism from organizations such as the Oromo Liberation Front (OLF), Patriotic Ginbot 7 (PG7) and the Ogaden National Liberation Front (ONLF), which are all classified by the Ethiopian parliament as terrorist organizations. In Ethiopia, it is common to grant an amnesty for thousands of prisoners on the occasion of celebrating New Year and Ethiopian Christmas.

\title{
5.6. Pardon
}

Pardon is defined in general terms as an executive action that mitigates or sets aside punishment for a crime. It releases the offender from entire punishment prescribed for offence and from disabilities consequent on his convictions, and reinstates his civil liberties (Black's Law, 1992). Pardon can be granted based on the recommendations submitted by the pardon boards usually for public interest. The FDRE constitution Article 71(7) and 299 of the Criminal Code states that a sentence may be remitted in whole or in part or commuted into a penalty of lesser nature or gravity by an act of pardon by the president of the country. Moreover, the conditions of pardon shall be governed by the pardon procedure Proclamation No. 840/2014, which shall not cancel the entry sentence and of which shall remain in the judgment register of the criminal and continues to produce its other effects. For instance, on 12 February 2020 the Ethiopian pardon board office head said that for the last six months they had received 2934 prisoner applications for pardon. The board then approved 1270 pardon applications and released them. He added that special situations such as seriously ill persons, aged and foreign prisoners were the beneficiaries of this pardon. Similarly, on April 2/2020 the Ethiopian government had released thousands of suspects and prisoners after the outbreak of the COVID-19 pandemic to reduce the number of causalities of coronavirus outbreaks in the prisons. The criteria for giving pardon were persons sentenced with simple imprisonment and prisoners with only one year left before being released on parole.

\subsection{Plea Bargaining}

Plea bargaining can be defined as a form of negotiation between the state and the defendant whereby the latter agrees to plead guilty in return to charge or sentence concessions (Black`s Law, 2004). It involves charge bargaining and sentence bargaining. The FDRE Criminal Justice Policy of Ethiopia (2011) article 4.5.4 states that the benefits of Plea bargaining are to enhance the efficiency of the criminal justice system, promote remorse and rehabilitation of offenders and also help in avoiding the trauma of trial for defendants and victims. The Attorney General has the power to plea bargain and decide alternative actions to be taken, following the implementation based on Proclamation No.691/2010 and Proclamation No.943/2016 Article 6(3)(d). It is also recognized by the Prevention and Suppression of Trafficking in Persons and Smuggling of Migrants Proclamation No. 909/2015 article 23 which states that:

\begin{abstract}
"Any person who involves in the crimes of trafficking in persons or smuggling of migrants and who, before the case is taken to the court, provides substantial evidence as to the offence and other suspects, may be fully or partially set free from prosecution upon the decision given by the Minister. When the victim dies, his organ is removed or if he is exposed to incurable disease, the suspect shall not be set free from prosecution; provided however, that depending on his participation and the usefulness of the evidence provided, his punishment shall be reduced."
\end{abstract}

The Anti-Terrorism Proclamation No. 652/2009 article 33 entitled “Assisting Judicial Proceedings" states that:

\begin{abstract}
"The court may mitigate the punishment, upon a request made by the public prosecutor where the defendant repents about his act of committing any of the crimes mentioned under this Proclamation and cooperates in elaborating in detail the manner of the commission of the crime or discloses the identities of the persons who participated in the commission of the crime."
\end{abstract}

The Ethiopian anti-corruption Proclamation No. 881/2015 article 8 provides that immunity is given to a co-offender who discloses substantial evidence concerning another co-offender by anti-corruption commission or the appropriate organ. Based on this article and to promote national consensus, the Ethiopian government pardons corruption suspects and negotiate with the corrupter to return the people's property.

\subsection{Community policing}

Please cite this article as: Ayalew, N. a. (2020). Basis and Practices of Restorative Justice: The Case of the Ethiopian Criminal Justice System. International Journal of Social Sciences and Economic Review, 2(3), 01-11. Doi: https://doi.org/10.36923/ijsser.v2i3.53. 
Community Policing is a philosophy, management style, and organizational design that promotes proactive problem solving and police community partnership to address the causes of crime, fear and other community issues (Morgan, 2011). The Ethiopian Federal police proclamation No 207/2000 Article 22 (4) also states that the activity of the police shall be based on the participation of the public. The police have established a community police partnership with different levels of community structures such as schools as well as religious and social institutions in order to resolve the problem together. In the Ethiopian community, policing has been practiced since 2010, specifically the community policing structure established from federal government up to family level which has been used to resolve their problems. Informants also added that community policing officers support traditional conflict resolution mechanisms to resolve local conflicts. Moreover, the community policing officer sometimes also acts as a mediator and arbitrator for criminal cases (G. B. Abubakar, 2019; Ayalew, 2019)This means that the community policing acts as a meeting point between the formal and informal conflict resolution mechanisms.

\subsection{Afarsata}

This refers to the participation the community in crime investigations. Whenever a person or a group of persons report to the local chief of the commission of certain crimes, the local chief would call on all male members of the community in that locality to assemble in a fixed place on a given date. A person who fails to attend such gathering would be liable to a fine. In the assembly, the elders would call upon each person to reveal who he suspects. Each person would declare the identity of the person he suspects or what had been told to him by the "singing bird". The person who would testify to the identity of the criminal under oath is kept secret and referred to as the "bird". The person thus identified as the offender is responsible for compensation of the victim. If the people failed to identify any person responsible for the alleged crime, the entire community would be liable to make the damage good. Later on, a circular letter is issued by the Ministry of Interior that requires the attendance of a policeman in all such meetings. This is similar with the family conference and sentence circle models of restorative justice.

\subsection{Shuttle Diplomacy}

An International Crisis Group report dated 17 June 2008 shows that in July 2007, the result of the 2005 national election had caused violence and the government had arrested the members of the opposition political party i.e. the Coalition for Unity and Democracy (CUD) in Ethiopia. Professor Ephrem Isaac, Haile Gebre silassie and Ambassador Bekele had attempted to mediate to get the CUD leaders released from jail. The mediators presented a document for signature by the CUD leaders, which reads: "We apologize for Ethiopians, the government and the mediators for the acts, which were outside of the constitution, committed by some of our members and supporters following elections 2005." The detainees were called from their respective cells whenever the mediators appear and asked to make decisions on the spot with the presence of the mediators. This put the arrested politicians in a weaker position and they were pardoned after signing documents admitting responsibility for the violence.

\subsection{Suspect Rehabilitation}

Article 35 of the FDRE criminal code states that:

Where two or more persons commit a crime in concert such as a conspiracy or a brawl that is committed by a group of persons, the person whose presence in the group is proven shall be exempt from punishment only if he proves that he has taken no part in the commission of the crime.

This article states that in case of a conspiracy or brawl, the burden of proof is on the suspected person to prove his innocence. If the crime was proven to have been committed, the participants are presumed to be guilty until proven innocent. For instance, in October 2015, the government declared a state of emergency based on the FDRE constitution article 93 that suspends the due process rights. But in November 2015, anti-government protests escalated and posed a threat to the government. The government conducted mass arrests and the protestors were sent to military camps without due process of law. About 24,000 people had been trained for over a month and released. But the mastermind of this violence was sent to formal criminal justice system. Similarly, in September 12-17 2018, following the welcome program for opposition political parties to Ethiopia, their supporters disagreed on which flag was to be displayed on the main road of Addis Ababa, which subsequently created violence. In order to control it, the police arrested 1,100 youths who were sent away for a month-long training before being released.

\subsection{Reconciliation}

This refers to the values of forgiveness for the past, lasting love, solidarity and mutual understanding by identifying the reasons of conflict, animosity that occurred due to conflicts, misapprehensions, developed disagreements and revenge pursuant to the Ethiopian proclamation number $1102 / 2018$ article 2(3). After mass violence, reconciliation is seen as a political imperative, an obliged passage for the survival of the society. In such a context, reconciliation does not necessarily lead to improved relationships; rather, it is about connecting with others. In other words, reconciliation is the outcome of the traditional conflict resolution mechanism (TCRM). Ethiopia has more than 80 different ethnic groups with their own form of TCRM, which has a legal recognition to resolve personal and family cases. Moreover, the criminal justice system often relies

Please cite this article as: Ayalew, N. a. (2020). Basis and Practices of Restorative Justice: The Case of the Ethiopian Criminal Justice System. International Journal of Social Sciences and Economic Review, 2(3), 01-11. Doi: https://doi.org/10.36923/ijsser.v2i3.53. 
on it to solve less serious cases like identity conflict, to bring criminals to courts, to ensure that verdicts are upheld and to achieve reconciliation after cases are concluded. Donovan and Getachew (2003) stated that the criminal system only governs the lives of the townspeople and the highlander farmers, but the nomadic pastoralist and rural society are governed by their TCRM. Moreover, in Ethiopia there is ethnic and religion based conflict, which results in damages on humans, their property and internal displacement. In order to resolve it, the government uses the traditional conflict resolution mechanism.

\section{CONCLUSION}

The formal criminal justice system is unable to ensure public security and created dissatisfactions with regards to its process and outcome. This led to the emergence of restorative justice, which focuses on the healing of the harm caused to the victim and restoring the personal and social relationship disrupted by criminal acts. The finding of this paper shows that the house of federation, peace minister, court, general attorney, and reconciliation commission have legal recognition to apply restorative justice values and principles. Additionally, customary conflict resolution mechanisms have defector recognition to resolve criminal cases especially identity based conflict. The common models of restorative justice in Ethiopia are mediation, withdrawal of charge, probation, pardon, amnesty, plea bargaining, shuttle diplomacy, suspect rehabilitation and reconciliation based on different laws. Therefore, the house of people representative should enact a comprehensive law on restorative justice whilst the general attorney should create awareness about restorative justice.

\section{REFERENCE}

Abubakar, G. B. (2019). Islamisation And Democratic Transition In The Post- Revolution Egypt. International Journal of Social Sciences and Economic Review, 1(1), 29-34. https://doi.org/10.36923/ijsser.v1i1.28

Ayalew, N. A. (2019). Duty Of Confidentiality In Arbitration Process In Ethiopia. International Journal of Social Sciences and Economic Review, 1(2), 92-100. doi:https://doi.org/10.36923/ijsser.v1i3.42

Black, H. C. (1992). BLACK'S LAW DICTIONARY 1891-1991. Centennial ed.

Capone, D. G., Zehr, J. P., Paerl, H. W., Bergman, B., \& Carpenter, E. J. (1997). Trichodesmium, a globally significant marine cyanobacterium. Science, 276(5316), 1221-1229.

D. O., Hoddinott, J., \& Taffesse, A. S. (2009). The impact of Ethiopia's Productive Safety Net Programme and its linkages. The journal of development studies, 45(10), 1684-1706.

Dekeyser, D., Duga, A. T., Verboven, P., Endalew, A. M., Hendrickx, N., \& Nuyttens, D. (2013). Assessment of orchard sprayers using laboratory experiments and computational fluid dynamics modelling. biosystems engineering, 114(2), 157-169.

DeKeyser, R. M. (2013). Age effects in second language learning: Stepping stones toward better understanding. Language Learning, 63, 52-67.

Donovan, D. A., \& Assefa, G. (2003). Homicide in Ethiopia: human rights, federalism, and legal pluralism. Am. J. Comp. L., $51,505$.

Endalew Lijalem Enyew. (2013). a Move towards Restorative Justice in Ethiopia: Accommodating Customary Dispute Resolution Mechanisms with the Criminal justice System, Master's Thesis in Peace and Conflict Transformation Faculty of Humanities, Social Sciences nd Education, University Of Troms $\varnothing$,

Fekadu, P. (2009). Underlying distinctions between ADR, shimglina and arbitration: a critical analysis. Mizan law review, $3(1), 105-133$.

Galtung, J. (2004). Violence, war, and their impact: On visible and invisible effects of violence. In Polylog: Forum for intercultural philosophy (Vol. 5, p. 6).

Gilligan Hill, R. F. (2002). Restorative justice and the absent victim: new data from the Thames Valley. International Review of Victimology, 9(3), 273-288.

Gilligan, D. O., Hoddinott, J., \& Taffesse, A. S. (2009). The impact of Ethiopia's Productive Safety Net Programme and its linkages. The journal of development studies, 45(10), 1684-1706.

Harris, N., \& Maruna, S. (2005). Shame, shaming and restorative justice: A critical appraisal. Handbook of restorative justice: A global perspective, 452-462.

Hill, R. F. (2002). Restorative justice and the absent victim: new data from the Thames Valley. International Review of Victimology, 9(3), 273-288.

McCold, P. (1998). Restorative justice: variations on a theme. Restorative justice for juveniles: Potentialities, risks and problems for research, 19-53.

Morgan, A. (2011). Police and crime prevention: Partnering with the community. Research and Public Policy Series 111, 5479.

Oswald, B. (2013). Informal Justice and United Nations Peace Operations. International Organizations Law Review, 10(1), 166-192.

UN Handbook on Restorative Justice. (2008).United Nations Declaration on the Rights of Indigenous Peoples, No.61/295 (2007) resolution 
Ward, T., \& Langlands, R. L. (2008). Restorative justice and the human rights of offenders: Convergences and divergences. Aggression and Violent Behavior, 13(5), 355-372.

Wojkowska, E. (2006). Doing Justice. How Informal Justice Systems can Contribute, Oslo: United Nations Development Programme Oslo Governance Centre.

Zehr, E. P., Komiyama, T., \& Stein, R. (1997). Cutaneous reflexes during human gait: electromyographic and kinematic responses to electrical stimulation. Journal of neurophysiology, 77(6), 3311-3325. 